\title{
Recusant Witnesses and the McCarthyite CONGRESSIONAL INVESTIGATIONS
}

\author{
Ross J. Corbett *
}

\begin{abstract}
This paper charts the Warren Court's handling of those convicted for contempt of Congress at the urging of the House Un-American Activities Committee and the Senate Subcommittee on Internal Security. An examination of the arguments made in the Court's various opinions-and by whom-reveals that the outcomes in these cases cannot be explained solely by the changing membership of the Court. Even when there were the votes to support the vigorous denunciations of the McCarthyite congressional investigations that found expression in dissents inspired by Watkins $v$. United States, the Warren Court took a more measured tone. That more measured tone was an attempt to avoid a repeat of the fractured Court amidst a public backlash that Warren had provoked with Watkins and marked a return to the Court's pre-Watkins use of formalism to bring about the just result.
\end{abstract}

\section{CONTENTS}

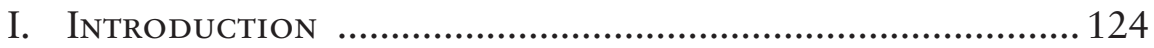

II. Contempt of Congress Under Vinson .............................. 125

III. Criminal Procedure: The Opening Salvo........................... 130

IV. Warren Shows His Hand: Watkins v. United States.......... 134

V. The Reaction Against Warren .......................................... 138

VI. Ending McCarthyite Investigations Through Formalism .... 143

\footnotetext{
* Ross J. Corbett received his Ph.D. in political science from the University of Toronto and his J.D. from Northwestern University School of Law. He is author of THE LOCKEAN COMMONWEALTH (2009) as well as articles on emergency powers, higher education policy, Aristotle, Machiavelli, Locke and natural law.
} 


\section{INTRODUCTION}

By the time Chief Justice Earl Warren decided his first case involving contempt of the House Un-American Activities Committee ("HUAC"), ${ }^{1}$ the only change to the composition of the Supreme Court since its now-infamous decision in Dennis $v$. United States ${ }^{2}$ was that he had replaced Chief Justice Fred Vinson and Justice John Marshall Harlan had replaced Justice Robert Jackson. On only one occasion was the new Chief Justice able to gain a majority of the Court to join in an opinion that denounced the goals of the that committee or its counterpart, the Senate Subcommittee on Internal Security ("SSIS"), rather than just the procedures followed in pursing those goals-Watkins $v$. United States. ${ }^{3}$ Throughout his entire sixteen-year tenure as Chief Justice, Warren either dissented from opinions upholding Congress's power to punish people for refusing to testify before (or turn over documents to) HUAC or SSIS, ${ }^{4}$ or was able to assemble a majority only for narrow, technical challenges to that power. ${ }^{5}$

These facts lend themselves to an easy narrative: Warren simply could not get enough votes to make his sweeping pronouncements in Watkins stick. That narrative, however, does not explain the last two decisions that the Warren Court issued concerning a then-moribund HUAC, Yellin v. United States ${ }^{6}$ and Gojack v. United States. ${ }^{7}$ These were also narrow, technical decisions. And by the time these cases were decided, 1963 and 1966, respectively, Warren likely did have five votes in favor of a free-expression attack on the entire system of McCarthyite congressional witch-hunts.

This paper charts the Warren Court's handling of those convicted for contempt of Congress at the urging of HUAC and SSIS. It concludes with a speculation concerning why Warren did not push for a sweeping denunciation of those committees in 1963 or 1966, namely that these cases marked a return to the Court's pre-Watkins use of formalism to bring about the just result.

1 Quinn v. United States, 349 U.S. 155 (1955).

Dennis v. United States, 341 U.S. 494 (1951).

Watkins v. United States, 354 U.S. 178 (1957).

4 Braden v. United States, 365 U.S. 431 (1961); Wilkinson v. United States, 365 U.S. 399

(1961); McPhaul v. United States, 364 U.S. 372 (1960); Barenblatt v. United States, 360 U.S. 109 (1959).

5 Gojack v. United States, 384 U.S. 702 (1966); Yellin v. United States, 374 U.S. 109 (1963); Grumman v. United States, 370 U.S. 288 (1962) (per curiam); Silber v. United States, 370 U.S. 717 (1962) (per curiam); Russell v. United States, 369 U.S. 749 (1962); Deutch v. United States, 367 U.S. 456 (1961); Flaxer v. United States, 358 U.S. 147 (1958); Sacher v. United States, 356 U.S. 576 (1958); Quinn v. United States, 349 U.S. 155 (1955); Emspak v. United States, 349 U.S. 190 (1955); Bart v. United States, 349 U.S. 219 (1955).

6 Yellin v. United States, 374 U.S. 109 (1963).

7 Gojack v. United States, 384 U.S. 702 (1966). 


\section{Contempt of Congress Under Vinson}

The House Un-American Activities Committee grew out of the anti-fascist Dies Committee, and quickly turned to focus on the tactics of the Communist Party. ${ }^{8}$ Its counterpart in the Senate, the Subcommittee on Internal Security, came into being in 1950 to monitor the enforcement of the McCarran Act and related laws. ${ }^{9}$ While each was nominally tasked with determining whether current espionage and security statutes were adequate to the subversive threat posed by Communism, they often did so by asking whether a particular citizen was or ever had been a member of the Communist Party. ${ }^{10}$ Both committees seemed concerned with ferreting out and exposing Communists for the sake of exposure, i.e., for the sake of punishing the individual rather than gathering information useful to the legislative process. ${ }^{11}$ They were not the only committees that engaged in this exposure process. ${ }^{12}$

The McCarthyite congressional committees could not punish Communists directly, for the most part-that task was left to the vigilantism of blacklists and public opprobrium-but they could punish those who did not cooperate in the identification of Communists. ${ }^{13}$ Central to that punishment was a nineteenth-century statute by which Congress had augmented its inherent power to punish contempt at the bar of the House or Senate by making that contempt into a crime punishable in the courts. ${ }^{14}$

Every person who having been summoned as a witness by the authority of either House of Congress to give testimony or to produce papers upon any matter under inquiry before either House, or any joint committee established by a joint or concurrent resolution of the two Houses of Congress, or any committee of either House of Congress, willfully

8 Morton J. Horwitz, The Warren Court and the Pursuit of Justice 54-55 (1998); Walter Goodman, The Committee: The Extraordinary Career of the House CommitteE ON Un-AMERICAN ACtivities 24-58 (1968).

9 Goodman, supra note 8, at 295.

10 See Lucas A. Powe, Jr., The Warren Court and American Politics 76-78 (2000); Martin H. Redish, The Logic of Persecution: Free Expression and the McCarthy ERA, 37-38 (2005).

11 See Powe, supra note 10, at 76-78.

12 Redish, supra note 10, at 37; cf. Christoffel v. United States, 338 U.S. 84, 85 (1949) (House Committee on Education and Labor).

13 See Horwitz, supra note 8, at 61 (contempt charges incentivized compliance with McCarthyite investigative committees); REDISH, supra note 10, at 37, 44.

14 See United States v. Bryan, 339 U.S. 323, 327 (1950) (contempt of Congress statute was enacted to enable contemnors to be jailed past the expiration of Congress's session); $c f$. Anderson v. Dunn, 19 U.S. 204, 230-31 (1821) (as an implied power necessary to effectuate its enumerated powers, Congress's authority to imprison for contempt at its own bar cannot extend past its current session). 
makes default, or who, having appeared, refuses to answer any question pertinent to the question under inquiry, shall be deemed guilty of a misdemeanor.....$^{15}$

The key phrases in this statute would turn out to be "pertinent," "willfully," and "under inquiry."

At first, it seemed as though the Vinson Court might force $\mathrm{McCa}$ rthyite congressional committees to respect the formalities of criminal due process, albeit in a case that involved perjury rather than contempt of Congress, Christoffel v. United States ${ }^{16}$ Harold Christoffel had been convicted of perjury for telling the House Committee on Education and Labor that he was not a Communist. ${ }^{17}$ Yet perjury had to be committed before a "competent tribunal," 18 while the quorum that was present when roll was called had dissipated by the time Christoffel denied being a Communist. ${ }^{19}$ Ignoring a dissent from Justice Jackson that, under the Rules of the House, the Committee had been a competent tribunal because no point of quorum had been raised, ${ }^{20}$ Justices Murphy, Minton, Frankfurter, Douglas, and Black voted to reverse the conviction. ${ }^{21}$ "We are measuring a conviction of crime by the statute which defined it," they wrote. ${ }^{22}$

The very next year, however, the Court was again faced with the criminal prosecution of a witness, Helen Bryan, who claimed at trial that there had been no quorum at the HUAC hearing at which she refused comply with a subpoena to produce records. ${ }^{23}$ Murphy was no longer on the Court, and Minton joined in an opinion written by Chief Justice Vinson in which the Court upheld Bryan's conviction. First, they argued, since the criminal contempt statute did not make any reference to a "competent tribunal," Christoffel was irrelevant: that the alleged contempt occurred before a competent tribunal was not an element of the offense. ${ }^{24}$ Second, Bryan's failure to object to a lack of quorum at the HUAC hearing both barred her from raising the issue at trial and demonstrated that the lack of a quorum did not materially disadvantage her. ${ }^{25}$ Lastly, the statute barring the use

152 U.S.C. § 192, formerly R.S. § 102, originally enacted in the Act of Jan. 24, 1857, c. $19, \S 1,11$ Stat. 155.

16 Christoffel v. United States, 338 U.S. 84 (1949).

17 Id. at 85 .

$18 I d$. at 85 n.2 (quoting 22 D.C. Code $\S 2501$ ).

19 Christoffel, 338 U.S. at 86.

20 Id. at 92-93 (Jackson, J., dissenting).

${ }_{21}$ Id. at $89-90$.

$22 \quad I d$. at 89.

23 United States v. Bryan, 339 U.S. 323, 324-27 (1950). Her constitutional objections to the subpoena were not before the Court, having prevailed in the Court of Appeals on the question of whether the competence of the committee was a question of law or fact. Id. at 327,343 .

24 Id. at 329-30.

25 Id. at 333-34. 
of congressional testimony in criminal proceedings other than those for perjury should not be read as barring its use in prosecuting contempt of Congress. ${ }^{26}$

Of these three arguments, the second was to reverberate most in the Warren Court. ${ }^{27}$ By contrast the first meant in essence that a witness who lied about being a Communist could raise the lack of quorum at trial, but not a witness who refused to answer the question at all.

It is the third argument, however, that is of greatest importance for understanding the fate of witnesses before McCarthyite congressional committees under the Warren Court. Technically, both Justices Black and Frankfurter dissented in United States v. Bryan (Justice Douglas did not participate in the case). ${ }^{28}$ Frankfurter, however, made it clear that he objected only to the Court's third argument regarding the admissibility of testimony before Congress. ${ }^{29}$ Thus Frankfurter was willing to demand that witnesses before a congressional investigative committee raise all objections there, and only a regard for the formalities of the criminal law could save a recalcitrant witness. In his dissent from a companion case, Frankfurter wrote that "regard for [congressional committees' power of testimonial compulsion] does not call for the slightest relaxation of the requirements of our criminal process." 30

Just as importantly, however, Frankfurter was willing to countenance an awful lot so long as legal forms were adhered to. The idea that one might inadvertently "waive" a defense by failing to raise it in a congressional investigation stands in stark contrast with the nature of a congressional investigation. It suggests that a witness must approach congressional inquiries as a possible prelude to criminal prosecution and thus be wary to preserve arguments for eventual trial and appeal. Yet Congress's authority to punish contempt depends upon its having a proper legislative purpose for its investigation. ${ }^{31}$ Congress might like to know, for example, why a debtor to the United States is insolvent, but unless it is contemplating impeaching a federal officer for extending credit to an insolvent debtor, Congress cannot undertake the clearly judicial function of investigating particular wrongs. ${ }^{32}$ Where Senators stand accused of insider trading, the

26 Id. at 335-43.

27 E.g., McPhaul v. United States, 364 U.S. 372, 379 (1960); United States v. Fleischman, 339 U.S. 349, 352 (1950); see also Yellin v. United States, 374 U.S. 109, 135-36 (1963) (White, J., dissenting); Deutch v. United States, 367 U.S. 456, 484-85 (1961) (Whittaker, J., dissenting).

28 Bryan, 339 U.S. at 343, 346.

29 Id. at 343 (Frankfurter, J., dissenting).

30 United States v. Fleischman, 339 U.S. 349, 380 (1950) (Frankfurter, J., dissenting) (citation omitted).

31 Sinclair v. United States, 279 U.S. 263, 294 (1929), overruled on other grounds, United States v. Gaudin, 515 U.S. 506 (1995); McGrain v. Daugherty, 273 U.S. 135, 173-74 (1927); see Kilbourn v. Thompson, 103 U.S. 168, 192-93 (1880).

32 Kilbourn, 103 U.S. at 192-93. 
Senate can investigate into whether a particular firm has made trades on behalf of Senators, but it cannot "intru[de] into the affairs of the citizen" or "seek to ascertain any facts as to the conduct, methods, extent, or details of the business of the firm in question." " 33 In upholding Congress's power to compel testimony from the Attorney General's brother concerning malfeasance in the Department of Justice, the Court reaffirmed, "neither house is invested with a 'general power' to inquire into private affairs and compel disclosures, but only with such limited power of inquiry" as is necessary to make its enumerated powers effective. ${ }^{34}$ The sorts of questions that might be pertinent in contemplating legislation have been expanded, but always in the context of a reiterated prohibition on actual investigation into the affairs of the citizen. ${ }^{35}$ The notion that a witness might waive a defense by failing to assert it before Congress, by contrast, treats investigative committees as analogous to trial courts or administrative adjudications. From the beginning, then, Justice Frankfurter seemed amenable to the least defensible aspect of the McCarthyite investigative committees, namely, the exposure and public shaming of individual Communists.

The fact that Frankfurter was willing to give McCarthyism some leeway comes out in a case that did not involve Communists, a case the significance of which was to become a bone of contention under Warren's Chief Justiceship, United States v. Rumely. ${ }^{36}$ That case involved the Committee for Constitutional Government, which had formed in order to oppose the New Deal and in particular to oppose support for organized labor. ${ }^{37} \mathrm{In} \mathrm{Au}-$ gust 1950, the House Select Committee on Lobbying Activities demanded that its secretary, Edward Rumely, produce a list of all the bulk purchasers of his organization's books. ${ }^{38}$ The House committee's chairman, Frank Buchanan, claimed that Rumely's organization spent lavishly on lobbying activities but had never disclosed its contributors, so the committee wanted to see whether the Lobbying Act should be amended in case these bulk purchases were actually disguised contributions to lobbyists. ${ }^{39}$ Of course, Rep. Buchanan's hearings were described in the conservative press at the time as an "iniquitous New Deal inquisition ... set out to intimidate opponents of Trumanism." ${ }^{40}$ When Rumely refused to turn over the records, he was convicted of contempt of Congress. ${ }^{41}$

33 In re Chapman, 166 U.S. 661, 668-69 (1897).

34 McGrain v. Daugherty, 273 U.S. 135, 173-74 (1927).

35 E.g., Sinclair, 279 U.S. at 294 (upholding broad inquiry into federal contracts concerning oil reserves as not "related merely to appellant's private or personal affairs").

36 United States v. Rumely, 345 U.S. 41 (1953).

37 Richard Polenberg, The National Committee to Uphold Constitutional Government, 1937-1941, 52 J. Ам. Нistory 582, 584-85 (1965).

38 Rumely, 345 U.S. at $42-43$.

3996 Cong. Rec. 13882 (Aug. 30, 1950) (statement of Rep. Buchanan).

40 Freedom of the Press on Trial, CHI. TRIB., Aug. 22, 1951, Part 1, at 20, http://archives. chicagotribune.com/1951/08/22/page/20/article/freedom-of-the-press-on-trial.

41 Rumely, 345 U.S. at 42. 
In this context, where there was no whiff of an international Communist conspiracy, Frankfurter thought that a congressional investigation might offend the First Amendment. ${ }^{42} \mathrm{He}$ used this suspicion to justify avoiding the constitutional question, however, deciding instead that the House resolution authorizing the Select Committee did not clearly authorize an investigation into all attempts to influence public opinion. ${ }^{43}$ The fact that the House as a whole must have thought Buchanan's inquiry relevant to an authorized investigation, considering that it approved his request to prosecute Rumely for contempt, was irrelevant, Frankfurter declared. ${ }^{44}$ "Rumely's duty to answer must be judged at the time of his refusal ... and cannot be enlarged by subsequent action of Congress." ${ }^{45}$ That is, where Communists were not concerned, Frankfurter (and even Vinson, Clark, Jackson, and Reed, who joined his opinion) would read a congressional committee's authorization narrowly if an investigation raised First Amendment concerns.

Justices Douglas and Frankfurter would have overturned Rumely's conviction based on the First Amendment, ${ }^{46}$ but the Court that Chief Justice Warren was to inherit was composed largely of justices who had found Communism to be significant enough of a threat to trump First Amendment concerns ${ }^{47}$ and who were willing to entertain a First Amendment objection to congressional investigations only where Communists were not involved. ${ }^{48}$ At least some procedural defects in a congressional committee's form had to be raised before the committee itself, lest a witness be barred from raising them as a defense to criminal contempt charges. ${ }^{49}$ Nonetheless, when Warren took his seat there was precedent that a congressional committee's authorization to ask a question had to be clear in order to sustain a conviction for contempt. ${ }^{50} \mathrm{~A}$ string of cases stating that Congress could not investigate the private affairs of citizens, or at least could inquire into them only pursuant to a valid legislative purpose, were still good law. ${ }^{51}$ Crucially, Justice Frankfurter was willing to abandon the Dennis majority in the name of strict adherence to the formalities of criminal law, even where Communists were concerned. ${ }^{52}$

42 Id. at $42-44$.

43 Id. at $45-47$.

44 Id. at $47-48$.

$45 \quad I d$. at 48.

46 Id. at 56-58 (Douglas, J., concurring in judgment).

47 See Dennis v. United States, 341 U.S. 494, 502-11 (1951); see also id. at 546-52 (Frankfurter, J., concurring in judgment).

48 Cf. Rumely, 345 U.S. at 45-47.

49 United States v. Bryan, 339 U.S. 323, 329-30 (1950).

50 Rumely, 345 U.S. at 46-47.

51 Sinclair v. United States, 279 U.S. 263, 294 (1929), overruled on other grounds, United States v. Gaudin, 515 U.S. 506 (1995); McGrain v. Daugherty, 273 U.S. 135, 173-74 (1927); In re Chapman, 166 U.S. 661, 668-69 (1897); Kilbourn v. Thompson, 103 U.S. 168, 192-93 (1880).

52 United States v. Bryan, 339 U.S. 323, 344 (1950) (Frankfurter, J., dissenting); id. at 346-48 (Black, J., dissenting); United States v. Fleischman, 339 U.S. 349, 365-77 


\section{Criminal Procedure: The Opening Salvo}

The Warren Court's first push against the power of McCarthyite congressional committees to punish for contempt came in a trio of cases decided in $1955,{ }^{53}$ Quinn v. United States, ${ }^{54}$ Emspak v. United States, ${ }^{55}$ and Bart v. United States. ${ }^{56}$ Where Bryan had required that witnesses follow certain formalities in order to preserve their objections to the composition of the committee, ${ }^{57}$ these cases compelled Congress to follow certain formalities if it wished to prosecute a person for contempt. Chief Justice Warren's majority opinions in these cases were joined by Justices Douglas and Black, as was to be expected, but also by Justices Frankfurter, Burton, and Clark. In Quinn, even Justice Minton joined the majority, while Justice Harlan, who had replaced Justice Jackson some months earlier, concurred in the judgment.

Thomas Quinn was a labor union field representative and had been subpoenaed to appear before a HUAC subcommittee along with two other union officers, Thomas Fitzpatrick and Frank Panzino. ${ }^{58}$ Fitzpatrick and Panzino testified first and both refused to answer questions about their membership in the Communist Party, the former mentioning the First and Fifth Amendments, the latter adopting Fitzpatrick's statement and mentioning the Fifth Amendment. ${ }^{59}$ The following day, however, Quinn said only that he supported the position advanced by Fitzpatrick and that the defense of constitutional principles forbade him to answer the question. ${ }^{60}$

The House was apparently of the opinion that there was no Fifth Amendment privilege against self-incrimination applicable to its investigations, since it referred all three for criminal prosecution for contempt of Congress. ${ }^{61}$ Whatever legal arguments the government put forward in support of that position, it was not seriously considered: both Fitzpatrick and Panzino were acquitted, ${ }^{62}$ with the District Court in the former's case saying only,

[t]here can be no doubt that [the privilege against self-incrimination] extends to a witness testifying before any judicial, congressional or admin-

(1950) (Black, J., dissenting); id. at 377-81 (Frankfurter, J., dissenting).

53 The Court had upheld a state's ability to punish a recusant HUAC witness by suspending his medical license the year before, but had not heard his challenge to his contempt conviction. Powe, supra note 10, at 78-79.

54 Quinn v. United States, 349 U.S. 155 (1955).

55 Emspak v. United States, 349 U.S. 190 (1955).

56 Bart v. United States, 349 U.S. 219 (1955).

57 Bryan, 339 U.S. at 333-34.

58 Quinn, 349 U.S. at 157.

59 Id. at $157-58$.

$60 \quad I d$. at 158 n.8.

61 Id. at 159.

62 Id. 
istrative body of the United States Government, although, apparently, there has been misapprehension on the part of some that it does not." 63

The Supreme Court's own treatment was brief: one paragraph of platitudes about self-incrimination followed by a three-sentence syllogism that Quinn was entitled to claim the privilege. ${ }^{64}$ Only Justice Reed suggested that the privilege against self-incrimination should not apply to congressional investigations, since the extension of that privilege beyond criminal trials was a matter of judicial discretion that could not be authoritative regarding Congress's own policy of compelling testimony before it. ${ }^{65}$ But not even Justice Minton joined Reed's dissent.

The significance of Quinn, then, is its near-unanimous, if muted, rebuke of the House regarding the reach of the Fifth Amendment. Given the privilege against self-incrimination, and given that the Smith Act exposes Communists to criminal liability, ${ }^{66}$ the Court acted as though the only real question was whether Quinn had invoked his privilege, which everyone other than Reed agreed he had. ${ }^{67}$

Warren also articulated an alternate ground for reversing Quinn's conviction, a ground from which only Reed and Harlan dissented. ${ }^{68}$ As a criminal statute, contempt of Congress requires criminal intent. ${ }^{69}$ The witness must know that an answer is demanded before a refusal to answer can be wrongful, and this requires that the committee expressly overrule any objections to the question. ${ }^{70}$ Because the HUAC subcommittee did not overrule Quinn's invocation of Fitzpatrick's objections, he could not be convicted of contempt of Congress. ${ }^{71}$

This aspect of the Quinn decision can only be seen as an attack on McCarthyite procedures. After all the objection offered by Fitzpatrick and invoked by Quinn read:

The Constitution of this country provides certain protection for minorities and gives the privilege for people to speak and think as they feel that they should and want to. It also gives the privilege that people can have opinions or beliefs that may be unpopular. In my opinion, it gives them the right to hold those opinions secret if they so desire. This is a protec-

${ }_{63}$ United States v. Fitzpatrick, 96 F. Supp. 491, 493 (D.D.C. 1951) (emphasis added).

${ }^{64}$ Quinn, 349 U.S. at 161-62.

${ }_{65} I d$. at 184-85 \& n.11 (Reed, J., dissenting).

${ }_{66} I d$. at $162 \mathrm{n} .29$ (majority opinion).

${ }_{67} I d$. at 162-63; id. at 171 (Harlan, J., concurring in part and dissenting in part); contrast $i d$. at $174-75$ (Reed, J., dissenting).

${ }_{68} I d$. at 165-70 (majority opinion); id. at 171 (Harlan, J., concurring in part and dissenting in part); $i d$. at 185-89 (Reed, J., dissenting).

69 Id. at 165 (majority opinion).

70 Id. at $165-66$.

${ }^{71} I d$. at 166. 
tion of the first amendment to the Constitution, supplemented by the fifth amendment. $^{72}$

Quinn, in saying he agreed with this sentiment, phrased it solely as the right to hold unpopular beliefs, that is, as a First Amendment issue. ${ }^{73}$ In order for his refusal to be made with the requisite criminal intent, on the Court's reasoning, the HUAC subcommittee would have had to have remembered that Fitzpatrick also made passing reference to the Fifth Amendment and expressly overruled that objection. As Reed's dissent makes clear, the Court was imposing a requirement for formulaic recitations on Congress at the same time as it was declaring that witnesses need not make any formulaic recitation in order to invoke their rights. ${ }^{74}$

The fact that the Court was taking aim at the informality of $\mathrm{McCa}$ rthyite congressional investigations as a whole, and not just the sloppiness of this particular HUAC subcommittee, is seen plainly in its parallel decision in Bart. ${ }^{75}$ There, the witness had refused to answer based on both the Fifth Amendment and the fact that the questions were not pertinent. ${ }^{76}$ The HUAC subcommittee chairman told the witness's lawyer, "[j] ust advise your client and don't argue with the committee, because we don't rule on objections."77 Yet the witness was then told the question's pertinence and that he was not being asked to incriminate himself. ${ }^{78} \mathrm{His}$ conviction was nonetheless overturned. ${ }^{79}$ What was at issue, therefore, must have been the informality with which HUAC subcommittees operated, the fact that they "don't rule on objections."

In Emspak the witness had seemed to disclaim a reliance on the Fifth Amendment at all, expressly denying that he was concerned that his answer would open him to criminal prosecution. ${ }^{80}$ Earlier in his testimony, however, he had stated, "I think it is my duty to endeavor to protect the rights guaranteed under the Constitution, primarily the first amendment, supplemented by the fifth. This committee will corrupt those rights." ${ }^{81}$ With this statement as a hook, the Court approached the question as one of whether Emspak had effectively waived his right, not whether he had invoked it, and as his waiver was not explicit, it was not valid. ${ }^{82}$

In finding that Emspak intended to rely on the Fifth Amendment in the first place, however, the Court set the bar very low. When Emspak was

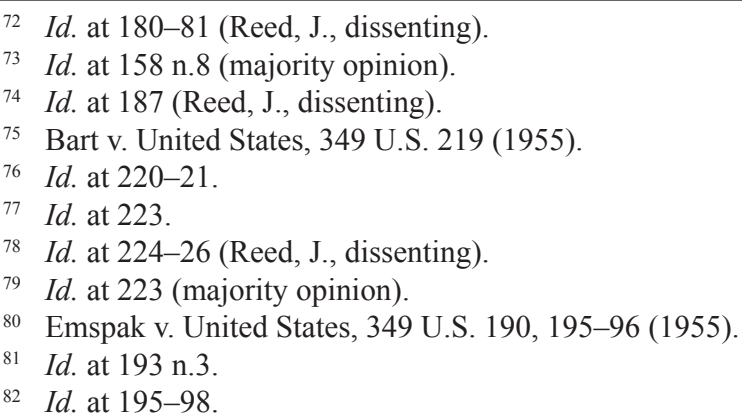


asked whether he knew a specific person, he began to make a statement on the nature of his job as a union representative, the importance of the Constitution, and how HUAC was bad for the labor movement. ${ }^{83} \mathrm{He}$ affirmed several times that he would answer the question; it was while reaffirming that he would in fact answer the question that he said he was defending the Constitution, primarily those rights protected by the First Amendment, as supplemented by the Fifth. ${ }^{84}$ The fact that Warren saw in this an invocation of the privilege against self-incrimination lost him the votes of Minton and Harlan, who had voted with him regarding Quinn. The extended quotations from the record that characterize the dissents in Quinn, Emspak, and Bart suggest that Warren stood accused of distorting that record. ${ }^{85}$

What the Court was in effect doing was demanding that congressional investigative committees conduct themselves more like an official tribunal, with formal rulings on objections, except that the objections themselves did not have to be made formally (or even very discernably) at all. On one hand, this demand validated the adversarial and potentially penal nature of the McCarthyite congressional committees, where in theory they could exist solely to solicit information Congress needed in order to legislate intelligently. ${ }^{86}$ On the other hand, however, those committees were pursuing individuals under the pretext of a legitimate legislative purpose, and unless the Court was going to put an end to the hearings altogether-a position for which there were neither the votes, the doctrine, nor the means of enforcement-compelling Congress to conduct itself like an adversarial tribunal was certainly an improvement. Yet the Court went beyond even this. In finding that even a passing reference to the Fifth Amendment counted as invoking it, even when the witness denied that answering would be incriminating, ${ }^{87}$ as did the bare adoption of another's statement that made passing reference to the Fifth Amendment in the course of defending the freedom to hold unpopular beliefs, ${ }^{88}$ Warren signaled to the McCarthyite investigative committees that the Court had between six and eight votes in favor of watching Congress's anti-Communist activities very closely for any procedural impropriety that might implicate criminal due process concerns.

Warren was able to assemble this coalition in 1955 for two main reasons. First, he did not touch the First Amendment claims raised by the defendants, ostensibly because the other grounds sufficed to dispose of the

83 Quinn v. United States, 349 U.S. 155, 176-78 (1955) (Reed, J., dissenting). Justice Reed published a single dissent to both Quinn and Emspak, and so his discussion of the latter occurs in the former.

84 Id. at 178 (Reed, J., dissenting).

85 Cf. Quinn, 349 U.S. at 176-82, 188 (Reed, J., dissenting); Emspak, 349 U.S. at 215-18

(Harlan, J., dissenting); Bart, 349 U.S. at 224-26 (Reed, J., dissenting); id. at 227-31

(Harlan, J., dissenting).

86 See notes 31-35 \& accompanying text, supra.

87 Emspak, 349 U.S. at 195.

88 Quinn, 349 U.S. at 158. 
cases. ${ }^{89}$ That ostensive justification is undercut by the fact that Warren offered parallel sufficient arguments in all three cases-each defendant had invoked the Fifth Amendment and evidence of criminal intent was lacking $^{90}$ — so his refusal to touch the First Amendment was probably strategic. Second, at issue was not simply Congress's power to conduct investigations or even to jail nonmembers for contempt before its own bar, but its desire to involve the judiciary in punishing contempt. This not only meant that a larger issue was at stake than simply the fate of a few Communists, but it also allowed Warren to take advantage of the momentum of Rumely's formalistic reasoning.

\section{Warren Shows His Hand: Watkins v. United States}

Everything that the Chief Justice was careful not to say in Quinn, Emspak, and Bart, he shouted in Watkins v. United States. ${ }^{91}$ What survived of the case-the propositions for which it was later cited by less amiable majorities-was the narrow, technical ground that Justice Frankfurter cast as its real holding. ${ }^{92}$ Contempt of Congress is a crime, meaning that the acts constituting the crime must be clear at the moment the defendant can avoid them. ${ }^{93}$ What the statute criminalizes is a refusal to answer "any question pertinent to the question under inquiry." 94 Thus, the scope of a congressional inquiry must be clear both for the witness to know that the question is pertinent and for the courts to judge whether the question the witness intentionally refused to answer was indeed pertinent. ${ }^{95}$ That clearly defined scope was lacking in Watkins' case. ${ }^{96}$

John Watkins had freely answered a HUAC subcommittee's questions about his own Communist activities and whether or not he knew specific persons, but he refused to say whether those he knew were members of the Communist Party. ${ }^{97}$ While the Court had suggested that acknowledging relationships with Communists might be incriminating, ${ }^{98}$ Watkins had already answered questions about whom he knew and in any case expressly refused

\footnotetext{
89 Quinn, 349 U.S. at 170; Emspak, 349 U.S. at 202; Bart, 349 U.S. at 223.

90 Quinn, 349 U.S. at 163-64, 170; Emspak, 349 U.S. at 201-2; Bart, 349 U.S. at 221-23.

91 Watkins v. United States, 354 U.S. 178 (1957).

92 See id. at 216-27 (Frankfurter, J., concurring).

93 Id. at 208 (majority opinion).

942 U.S.C. § 192; Watkins, 354 U.S. at 207-8.

95 Watkins, 354 U.S. at 208-9.

96 Id. at 209-15.

97 Id. at $182-85$.

98 Emspak v. United States, 349 U.S. 190, 198-201 (1955).
} 
to plead the Fifth Amendment. ${ }^{99} \mathrm{He}$ instead insisted that questions about other people were not relevant to the subcommittee's work and that it could have no authority to expose them publicly because of past activities. ${ }^{100}$ Watkins in effect challenged the legitimacy of what HUAC was actually doing.

Unlike in Quinn, Emspak, and Bart, Warren's Watkins opinion did not avoid the First Amendment issue. ${ }^{101}$ What is surprising is not that he touched it-McCarthyism certainly raised First Amendment concerns, even granting what we now know about the extent of Soviet infiltration during the Cold War ${ }^{102}$ - but that he did so little with it. He laid out an argument, but he did not draw the conclusion from it. ${ }^{103}$ Congress's power to conduct investigations is broad, but not absolute, he said. ${ }^{104}$ Not only must an investigation be justified in terms of Congress's functions, ${ }^{105}$ but even a justified investigation must comport with the Bill of Rights, including the rights against self-incrimination, unreasonable search and seizure, and abridgement of free speech, belief, or association. ${ }^{106}$ These limits may be enforced on judicial review even when Congress punishes contempt at its own bar, ${ }^{107}$ and so a fortiori when it instead delivers the contemnor to the judicial branch for punishment. ${ }^{108}$ Abuse of the investigative process may abridge political freedoms by exposing the adherents of unorthodox beliefs to public censure, ${ }^{109}$ and so Congress's need for information can be accommodated only by the courts' discerning "the existence of, and the weight to be ascribed to, the interest of the Congress in demanding disclosures from an unwilling witness." 110

These arguments set up any one of several conclusions, but Warren does not draw any of them. He could have concluded that there is no valid legislative purpose in ferreting out individual Communists and that this is what the HUAC subcommittee was doing with Watkins. He could have said that, even though HUAC had a valid legislative purpose in knowing the extent of the Communist threat the nation faced, that purpose would

\footnotetext{
99 Watkins, 354 U.S. at 185.

100 Id.

101 Id. at 188, 197-98.

102 See Redish, supra note 10, at 3-8, 42-43 (Soviet activities as disclosed in Comintern and Verona documents justified anti-espionage and anti-sabotage actions, not the suppression of free speech sanctioned in Barenblatt and other decisions upholding McCarthyism).

103 See Powe, supra note 10, at 96-97; REDISH, supra note 10, at 40-42.

104 Watkins, 354 U.S. at 187.

105 Id.

106 Id. at 188.

107 See id. at 192 (congressional contempt, unlike that of the English Parliament, has always been subject to judicial review).

108 See id. at 206-208 (when Congress refers a contemnor for punishment under 2 U.S.C. $\S 192$, the courts must afford every protection of the criminal law).

109 Id. at $197-98$.

110 Id. at 198.
} 
be so little advanced by discovering the political beliefs and associations of particular individuals in a nation of over one-hundred sixty million that the First Amendment forbade such inquiries. But he did not.

Instead, Warren noted that the House or Senate must set the boundaries of their investigative committees and that a vague authorizing resolution makes it more possible for the committee to deviate from the House's or Senate's will. ${ }^{111}$ Turning to the resolution authorizing HUAC, in particular ("Rule 11"), Warren remarked, "[i]t would be difficult to imagine a less explicit authorizing resolution." "112 That lack of clarity frustrates the task of judicial review, ${ }^{113}$ preventing the courts from "strik[ing] a balance between the public need for a particular interogation and the right of citizens to carry on their affairs free from unnecessary governmental interference." 114 But again Warren did not draw a salient conclusion from this: he did not say that, where Congress's interest in the information is not clear, inquiries into an individual's political beliefs and associations violate the First Amendment.

The reason why Warren did not draw any of these conclusions seems rather clear: an opinion that garners only four votes is not controlling. Minton and Reed were no longer on the Court, but the former's replacement by Justice Brennan was offset by Clark's shift to the dissent in Watkins. ${ }^{115}$ Formerly, Clark had voted in favor of strict criminal due process protections for those accused of contempt of Congress, ${ }^{116}$ but now rejected even Frankfurter's understanding of the Watkins decision, ${ }^{117}$ having stated at conference that making prosecution in the courts too difficult "would throw these people into the fire" by causing Congress to try them before its own bars, where "the witness has no lawyer and no appeal."118 While Watkins was ultimately decided six to one, Frankfurter made it clear that he joined only regarding criminal due process ${ }^{119}$ and at conference suggested that he was

111 Id. at 201

$112 I d$. at 202.

${ }_{113} I d$. at 204-5.

${ }^{114} I d$. at 205-6.

115 Watkins, 354 U.S. at 217 (Clark, J., dissenting).

116 Quinn v. United States, 349 U.S. 154 (1955); Emspak v. United States, 349 U.S. 190 (1955); Bart v. United States, 349 U.S. 219 (1955); United States v. Rumely, 345 U.S. 41 (1953).

117 See Watkins, 354 U.S. at 225-27 (Clark, J., dissenting) (discussing whether the pertinence of the subcommittee's question was clear enough for a refusal to answer to be proof of the requisite criminal intent).

118 The Supreme Court in Conference (1940-1985), 299 (Dickson ed. 2001); cf. Marshall v. Gordon, 243 U.S. 521, 545 (1917) (the exercise of Congress's implied power to punish contempt in order to coerce compliance (but not punish past behavior) is not subject to judicial review, except for "an absolute disregard of discretion and a mere exertion of arbitrary power coming within the reach of constitutional limitations.").

${ }_{119} I d$. at 216-17 (Frankfurter, J., concurring). 
averse to cabining Congress's investigative power. ${ }^{120}$ Harlan's subsequent decision in Barenblatt $v$. United States shows that he thought HUAC's work important enough to overcome most First Amendment challenges. ${ }^{121}$

Yet if Warren could not get the votes for the conclusions flowing from the premises he laid out, then his inclusion of those premises at all becomes perplexing. As a practical matter, the precedential value of his statements depended upon five justices supporting them in a future case, not their presence on the pages of the United States Reports. To the extent that members of his majority disagreed with those statements, their likely effect was to antagonize justices upon whose votes he would have to rely. He had said nothing about the First Amendment in conference, instead noting that this was a good case to state the due process limits on Congress's power to punish through the judiciary. ${ }^{122}$ Frankfurter's response was that "[w]e should not talk big in this field." 123

Warren not only talked big in this case, but the manner in which he did so was certain to alienate Frankfurter and Harlan. He cited Rumely for the proposition that "the mere semblance of legislative purpose [will] not justify an inquiry in the face of the Bill of Rights," ${ }^{124}$ when Frankfurter had assiduously avoided reaching the constitutional issue. ${ }^{125}$ When Warren said that a less explicit resolution than that authorizing HUAC was difficult to imagine, he telegraphed his doubts that there was any such thing as "UnAmerican" or a "single, solitary "principle of the form of government as guaranteed by our Constitution." "126 Warren was laying the foundation for limiting Congress's investigative power; Frankfurter said that the only case in which Congress was held to have exceeded that power was flawed. ${ }^{127}$ Warren not only lost his majority within two years, but so alienated his colleagues that they rejected challenges to McCarthyite investigations even where it was clear that the committees were out of control. A decade later, one commentator on HUAC concluded that "the Chief Justice was merely indulging himself." 128

${ }^{120}$ Supreme Court In Conference, supra note 118, at 298-99.

121 See Barenblatt v. United States, 360 U.S. 109, 125-34 (1959).

122 Supreme Court In Conference, supra note 118, at 297.

${ }^{123} \mathrm{Id}$. at 298.

124 Watkins, 354 U.S. at 198; see also id. at 197 n.31 (Rumely permits the First Amendment to be invoked against an overly broad congressional investigation); id. at 204-205 (Rumely requires a balancing test between Congress's interest in the information and the witness's First Amendment rights).

${ }^{125}$ United States v. Rumely, 345 U.S. 41, 43-44 (1953).

126 Watkins, 354 U.S. at 202.

127 Supreme Court in Conference, supra note 118, at 298-99. The case Frankfurter referred to was Kilbourn v. Thompson, 103 U.S. 168 (1880).

${ }^{128}$ Goodman, supra note 8, at 360. 


\section{The Reaction Against Warren}

The broad statements in Watkins were not reflected in subsequent Supreme Court decisions. The Court decided two cases involving contempt of Congress in between that case and Barenblatt $v$. United States a mere two years later. In Sacher $v$. United States, the Watkins majority voted to overturn a conviction for refusing to answer a question that was not pertinent to a SSIS investigation. ${ }^{129}$ In Flaxer $v$. United States, a unanimous Court overturned the conviction of a witness who had declared that he would not produce documents for SSIS: because the subcommittee had given him ten days in which to comply, his refusal the day of the hearing did not suffice for the criminal intent to refuse to produce the documents ten days later. ${ }^{130}$ Both were technical rulings based on the protections of the criminal law.

One explanation for the Court's renewed incrementalism involves Congress's reaction to what was decried as Red Monday, the day on which Watkins and a series of other cases targeting McCarthyism were announced. ${ }^{131}$ Senator William Jenner introduced a bill to limit the Supreme Court's appellate jurisdiction over subversive activities, ${ }^{132}$ including "any case where there is drawn into question the validity of ... any action or proceeding against a witness charged with contempt of Congress." 133 This provision was stripped from the bill by an amendment offered by Senator John Marshall Butler, ${ }^{134}$ but the Judiciary Committee replaced it with an amendment to the contempt of Congress statute itself stating that a question would be deemed "pertinent" if (1) no objection was made at the hearing or (2) the question was ruled pertinent by the committee, with the presiding officer's ruling standing as the ruling of the body unless overruled. ${ }^{135}$ Although the Jenner-Butler Bill made it out of committee, it was never taken up for a vote. ${ }^{136}$

129 Sacher v. United States, 356 U.S. 576, 577-78 (1958) (per curiam).

130 Flaxer v. United States, 358 U.S. 147, 151 (1958).

131 Horwitz, supra note 8, at 59, 64-65; Powe, supra note 10, at 127-34, 141-42.

132 Ira Mickenberg, Abusing the Exceptions and Regulations Clause: Legislative Attempts to Divest the Supreme Court of Appellate Jurisdiction, 32 AmericAN U. L. Rev. 497, 503 (1983).

133 S. 2646, 85 ${ }^{\text {th }}$ Cong. $1^{\text {st }}$ Sess. (1957), quoted in Mickenberg, supra note 132, at 503 n. 41.

134 Powe, supra note 10, at 31; Mickenberg, supra note 132, at 504.

135 S. REP. No. 85-1586, at 5 (1958), available at http://congressional.proquest.com /congressional/docview/t47.d48.12062_s.rp.1586. The bill was originally going to be taken up by the Judiciary Committee based solely upon SSIS's findings, but the Judiciary Committee's chairman suggested that full hearings be conducted, and Senator Jenner's motion to table that suggestion failed by a single vote. Powe, supra note 10, at 102 .

${ }_{136}$ Mickenberg, supra note 132, at 504-5. The motion to table the bill passed 49-41. PowE, supra note 10 , at 132 . 
At any rate, Chief Justice Warren found himself in the dissent in Barenblatt. ${ }^{137}$ Not much need be said about the majority opinion, other than that it affirmed what Frankfurter and Harlan liked about Watkins while emphatically rejecting what they disliked. Watkins did not hold that Rule 11 was impermissibly vague, Harlan wrote for the majority, but rather that the pertinence of a question had to be clear in order to sustain a conviction, and the pertinence of a question can be gleaned from sources other than the investigative committee's authorizing resolution. ${ }^{138}$ Watkins was also distinguishable in that there the witness did not receive a satisfactory answer to his pertinence objection, while Barenblatt's reservation of his right to raise pertinence objections in general did not count as a particular objection to which the subcommittee had to respond at all. ${ }^{139}$ Because of the threat posed by Communism, the Court continued, the First Amendment is not offended by compelling witnesses to disclose their political affiliations. ${ }^{140}$

Freed from the imperative to garner a majority, Black's dissent called a spade a spade. ${ }^{141}$ HUAC's mandate was too vague, and as the pertinence of a question can come only from that mandate, no prosecution for failing to answer any question asked by any HUAC subcommittee could be sustained. ${ }^{142}$ HUAC's activities were designed to curtail speech, and no balancing test could save such an unconstitutional legislative purpose. ${ }^{143}$ The threat of Communism did not justify any departure from the First Amendment, since stifling debate is unnecessary to the preservation of the nation. ${ }^{144}$ And as the real aim of the McCarthyite activities was to punish

${ }^{137}$ Barenblatt v. United States, 360 U.S. 109, 134 (1959) (Black, J., dissenting).

${ }^{138}$ Barenblatt, 360 U.S. at 116-23 (majority opinion).

${ }^{139} \mathrm{Id}$. at 123-24. The Court also held that the questions put to Barenblatt were pertinent as a matter of law. Id. at 124-25. At the time, pertinence was a question of law. See Sinclair v. United States, 279 U.S. 263, 298-99 (1927). Two years later, however, the Court would treat pertinence as a question of fact that must be proven beyond a reasonable doubt, without expressly overruling Sinclair. Deutch v. United States, 367 U.S. 456, 469-71 (1961); cf. United States v. Gaudin, 515 U.S. 506, 519-22 (1995) (pertinence is a question of fact, expressly overruling Sinclair).

140 Barenblatt, 360 U.S. at 125-34. The Court had made the clear and present danger test into a balance of harm versus freedom (thus eliminating the need for the danger to be imminent) in Dennis v. United States. 341 U.S. 494, 510 (1951); see id. at 524-26 (Frankfurter, J., concurring); HoRwITz, supra note 8, at 58. See also Watkins v. United States, 354 U.S. 178, 205-6 (1957) (courts must know Congress's interest in order to "strike a balance between the public need for a particular interogation and the right of citizens to carry on their affairs free from unnecessary governmental interference").

${ }^{141}$ Cf. Barenblatt, 360 U.S. at 134 (Black, J., dissenting). Curiously, Brennan did not join Black's dissent, instead writing separately to note his agreement with Black that HUAC's aim was solely to punish individuals. Id. at 166 (Brennan, J., dissenting).

${ }^{142}$ Id. at $137-40$ (Black, J., dissenting).

${ }^{143} I d$. at 141-42 (Black, J., dissenting).

${ }^{144}$ Id. at 145-46 (Black, J., dissenting). 
individuals for their unorthodox beliefs, HUAC impermissibly encroached upon the exclusive preserve of the judiciary. ${ }^{145}$

What is remarkable is not so much the Court's repudiation of where Warren wanted to go in Watkins. He had lacked the votes to write something along the lines of Black's dissent from Barenblatt, but had tried to lay the legal foundation for it anyway. What is instead remarkable is how far the Barenblatt majority was willing to go in subsequent cases in order to avoid acknowledging any merit whatsoever to the concerns expressed in Watkins.

Arthur McPhaul had been convicted of contempt of Congress in 1954 for a willful failure to comply with a subpoena to produce the records of the Civil Rights Congress. ${ }^{146}$ He refused to say whether those documents were in his possession or control, citing the Fifth Amendment, ${ }^{147}$ he presented no evidence at trial, ${ }^{148}$ and the only evidence suggesting he had any connection to the Civil Rights Congress was not submitted to the jury. ${ }^{149}$ When the Court upheld his conviction in 1960, it inscrutably argued that Bryan (a case about accidentally waiving defenses) ${ }^{150}$ required that McPhaul answer the subcommittee's questions about whether he was able to comply with its subpoena. ${ }^{151}$ The only thing the Court said to McPhaul's claim that he could not answer without incriminating himself was that "there is no merit in Petitioner's argument." 152 His refusal to answer these questions, therefore, provided the prima facie case for willful refusal to comply with a subpoena, thus shifting the burden of proof to him to show that he could not comply. ${ }^{153}$

It was of no avail for Justice Douglas to point out in his dissent that the burden of proof can shift to a defendant only after the government has shown at trial some connection between the witness and the subpoenaed documents. ${ }^{154}$ His plea that, "when it comes to criminal prosecutions, the Government must turn square corners" 155 echoed the Court's earlier cases protecting the due process rights even of Communists. ${ }^{156}$ Douglas's argu-

\footnotetext{
145 Id. at 154-63 (Black, J., dissenting).

146 McPhaul v. United States, 364 U.S. 372, 373-76 (1960). The events transpired in 1952, but he was not indicted until 1954.

147 Id. at 375.

${ }_{148} \mathrm{Id}$. at 377.

149 Id. at 377 n.4.

150 United States v. Bryan, 339 U.S. 323, 333-34 (1946).

151 McPhaul, 364 U.S. at 379.

152 Id. at 380.

${ }^{153} I d$. at $379-80$.

154 McPhaul, 364 U.S. at 384-87 (Douglas, J., dissenting).

155 Id. at 387 (Douglas, J., dissenting).

156 See Quinn v. United States, 349 U.S. 155, 165 (1955); Emspak v. United States, 349 U.S. 190, 202 (1955); Bart v. United States, 349 U.S. 219, 223 (1955); Christoffel v. United States, 338 U.S. 84, 89 (1949). One of the questions that Emspak had refused to answer was whether he was a member of the Civil Rights Congress. Emspak, 349
} 
ment did not mention, let alone rely on, the First Amendment or the impermissible vagueness of Rule 11. Frankfurter and Harlan nevertheless voted with the rest of the Barenblatt majority to uphold the conviction.

Even more shocking was the Court's sustaining the convictions of Frank Wilkinson and Carl Braden the following year. ${ }^{157}$ When a HUAC subcommittee was convened in Atlanta in 1958, Wilkinson travelled there to protest its activities. ${ }^{158} \mathrm{He}$ was immediately subpoenaed and asked if he was a Communist. ${ }^{159}$ Braden had forwarded two petitions to Congress, one opposing anti-sedition laws on the grounds that they were being used to target civil rights activists, the other accusing HUAC of targeting liberal and independent thinkers rather than Communists; the HUAC subcommittee summoned him to testify. ${ }^{160} \mathrm{He}$ was asked if he was a Communist "the instant you affixed your signature to that letter," referring to the first petition. ${ }^{161}$ Both men refused to answer, citing the First Amendment, and were convicted of contempt. ${ }^{162}$

Whatever political inclinations both men might have had, it could not have been any clearer that they were targeted for their opposition to $\mathrm{McCa}$ rthyism, not any activities related to Communist sabotage, espionage, or infiltration of core industries. ${ }^{163}$ The Court nevertheless refused to intervene. "These circumstances ... do not necessarily lead to the conclusion that the subcommittee's intent was personal persecution of the petitioner," it said in Wilkinson. ${ }^{164}$ If Wilkinson's opposition to HUAC was based on his being a Communist, HUAC was entitled to know that. ${ }^{165}$ And given HUAC's mandate, "Are you a Communist?" is always a pertinent question. ${ }^{166}$ Of Braden's assertion that he was targeted solely for engaging in protected political advocacy, the Court said only that the subcommittee believed he was

U.S. at 193. Five months after the Court reversed Emspak's conviction, the Subversive Activities Control Board labeled the Civil Rights Congress a Communist front organization. See Patterson v. Subversive Activities Control Bd., 322 F.2d 395, 396 (D.C. Cir. 1963).

157 Wilkinson v. United States, 365 U.S. 399 (1961); Braden v. United States, 365 U.S. 431 (1961).

158 See Wilkinson, 365 U.S. at 411.

${ }^{159} \mathrm{Id}$. at 416 (Black, J., dissenting).

160 Braden, 365 U.S. at 439 (Black, J., dissenting).

${ }^{161} I d$. at 434 (majority opinion).

162 Wilkinson, 365 U.S. at 404-6; Braden, 365 U.S. at 432.

163 Wilkinson, 365 U.S. at 417-18 (Black, J., dissenting); id. at 425 (Douglas, J., dissenting); id. at 429-30 (Brennan, J., dissenting); Braden, 365 U.S. at 450-51, 455-56 (Douglas, J., dissenting); Powe, supra note 10, at 147.

164 Wilkinson, 365 U.S. at 411 (majority opinion) (emphasis added).

${ }^{165} \mathrm{Id}$. at 414. The majority in Wilkinson suggested that there was some evidence that the petitioner was a Communist, but the only specifics provided involved HUAC's identification of anyone opposed to its activities as a Communist. See id. at 411-13.

${ }^{166} I d$. at 413. 
a Communist and was investigating appropriately. ${ }^{167}$ In effect, a criminal defendant would have to prove HUAC's malicious intent beyond a doubt, and not even just beyond a reasonable doubt, in order to avoid conviction for contempt of Congress.

In these opinions, the Court did not simply refuse to declare $\mathrm{McCa}$ rthyite investigative committees to be a violation of the First Amendment, as Black had done in his Barenblatt dissent and Warren had stopped just short of doing in Watkins. It shielded those committees from any First Amendment scrutiny whatsoever. And it did not do so on habeas corpus petitions from those imprisoned following trial at the bar of the House or Senate, but in sustaining criminal convictions before Article III courts. Justices Clark, Frankfurter, Harlan, Whittaker, and Stewart had rejected the relevance of the First Amendment entirely. And as McPhaul shows, they had grown impatient with criminal due process, as well.

A fourth case suggests that Justice Stewart, at least, did not vote to uphold those convictions out of fear of McCarthyism (and given Senator Jenner's retirement ${ }^{168}$ and the movement's increasing irrelevance, ${ }^{169}$ it is unclear how much this fear might have affected Justices Frankfurter and Harlan at that point, either). Bernhard Deutch was a college student who told a HUAC subcommittee investigating Communist infiltration of Albany labor unions about his own Marxist dabblings at Cornell. ${ }^{170}$ When he refused to name other Communists at Cornell, however, he was indicted and convicted for contempt of Congress. ${ }^{171}$ Like Watkins before him, he had done the "honest" thing, confessing his own acts but refusing to be an informer. ${ }^{172}$

Here, the same Stewart who had authored the contemptuously cynical opinions in Wilkinson and Braden and joined Whittaker's opinion in $\mathrm{McPhaul}$ wrote an opinion joined by Warren, Douglas, Black, and Brennan reversing Deutch's conviction on a slender technicality. With nary a word about Bryan, ${ }^{173}$ Stewart brushed aside the point that Deutch had not raised an objection to the subcommittee's inquiry's pertinence at the hearing. ${ }^{174}$ Ignoring (without addressing or overturning) the still-operative rule that

167 Braden, 365 U.S. at 435.

${ }^{168}$ His final term ended January 3, 1959. Jenner, William Ezra, Biographical DictionarY of the United States Congress, http://bioguide.congress.gov/scripts/biodisplay. pl?index $=\mathrm{J} 000093$.

169 See Goodman, supra note 8, at 399-402.

170 Deutch v. United States, 367 U.S. 456, 459-61 (1961).

${ }^{171} I d$. at 461 .

172 Cf. Supreme Court in Conference, supra note 118, at 297 (Warren's description of Watkins).

${ }^{173}$ Cf. Deutch, 367 U.S. at 457-58 \& n.2 ("we brought the case here because of doubt as to the validity of the conviction in the light of our previous decisions," listing Bryan as one of thirteen such decisions).

${ }^{174}$ Id. at 469. Contrast id. at 484-85 (Whittaker, J., dissenting) (failure to raise objection is decisive under Bryan). 
pertinence was a question of law, ${ }^{175}$ and his own pronouncement on the pertinence of a question as a matter of law in Wilkinson, ${ }^{176}$ Stewart wrote that, objection or no, the government still had the burden of proving pertinence at trial beyond a reasonable doubt-and to prove not only that the question was pertinent, but that its pertinence had been brought home to the witness such that his refusal to answer evinced criminal intent. ${ }^{177}$ As Ithaca is not in the Albany area, he continued, the government failed to prove that a question about Cornell's Marxist faculty and students was pertinent to Albany's labor unions. ${ }^{178}$ Justice Stewart, born in Michigan and having practiced law in Ohio, ${ }^{179}$ apparently did not accept Justice Harlan's suggestion that "in common usage, at least among New Yorkers, 'Albany area' would be regarded as aptly descriptive of 'upstate' New York." 180 So it cannot be said that the law compelled Justice Stewart to take the position he did in Deutch. But that makes Wilkinson and Braden seem all the more thymotic.

\section{Ending McCarthyite Investigations Through FORMALISM}

Chief Justice Warren did not find himself in the minority on any case concerning McCarthyite congressional investigations after 1961. ${ }^{181}$ Deutch represented the last case on the issue in which Justices Frankfurter and Whittaker participated. The latter was replaced by Justice Byron White, but the former's successor was Justice Arthur Goldberg. Aside from Yellin $v$. United States, ${ }^{182}$ Warren now had the support of Justice Stewart. Indeed, not counting Yellin, Stewart was the only justice to vote with the majority on every case involving contempt of Congress between 1958 and 1966,

175 Sinclair v. United States, 279 U.S. 263, 298-99 (1929) The Court would later characterize Deutch as "contradict[ing the] assumption" on which Sinclair was founded, before making it clear that Sinclair was no longer good law on this matter. United States v. Gaudin, 515 U.S. 506, 520 (1995).

176 Wilkinson v. United States, 365 U.S. 399, 413 (1961).

177 Deutch, 367 U.S. at 467-68, 469-70.

${ }_{178} I d$. at $470-71$.

179 Stewart, Potter, Biographical Directory of Federal Judges, http://www.fjc.gov/servlet/nGetInfo?jid=2294.

${ }^{180} I d$. at 474 (Harlan, J. dissenting). Justice Harlan's entire legal career had been centered in Manhattan until his elevation to the Court. Harlan, John Marshall, BIOGRAPHICAL Directory OF Federal Judges, http://www.fjc.gov/servlet/nGetInfo?jid=979.

${ }^{181}$ The one contempt of Congress case in which he found himself in the minority, Hutcheson v. United States, 369 U.S. 599 (1962), was unrelated to McCarthyism.

182 Yellin v. United States, 374 U.S. 109 (1963). 
when the last major Warren-era case was decided. ${ }^{183}$ The cases in which Stewart voted with Warren focused on criminal procedure, but as demonstrated by McPhaul and Deutch, Stewart was perfectly willing to force the rules of criminal procedure to bend to his desired result.

The Court next turned to six cases dating back to 1955 involving both HUAC and SSIS. In Russell v. United States, the Court reversed all six convictions since the indictments had failed to state "the question under congressional committee inquiry as found by the grand jury," thus preventing the courts from discerning whether the questions the witnesses refused to answer were pertinent and whether the trial jury convicted on the same theory upon which the grand jury had indicted. ${ }^{184}$ Never mind that the Court had never required an indictment to include the subject under inquiry in the previous 105 years of the contempt of Congress statute, ${ }^{185}$ or that the courts were liberalizing pleading standards in criminal indictments, not enforcing technicalities. ${ }^{186}$ Even a defendant who failed to raise the issue of the indictment with the Court of Appeals or make any argument concerning it to the Supreme Court could have his conviction overturned as a matter of plain error. ${ }^{187}$ Justice Stewart's majority opinion in Russell was joined by Warren, Douglas, Black, and Brennan. ${ }^{188}$

Douglas wrote separately to again fly the flag of free expression and association: "[w]hile I join the opinion of the Court, I think it is desirable to point out that in a majority of the six cases that we dispose of today no indictment, however drawn, could in my view be sustained under the requirements of the First Amendment." ${ }^{89}$ The committees had expressly targeted the New York Times, and there could be no valid legislative purpose where Congress was powerless to legislate (such as a restriction on the freedom of the press). ${ }^{190}$

What is surprising is that no one took up that flag the following year in Yellin. ${ }^{191}$ In that case, the Chief Justice did not enjoy Stewart's support (or that of Clark, Harlan, or White). Justice Goldberg, however, provided the crucial fifth vote. Yet the majority opinion, admitting that the Court had granted certiorari precisely because of the importance of the constitutional issues, decided the case on nearly inscrutable technical grounds. ${ }^{192}$ Edward Yellin did not want to be publicly embarrassed by his testimony, so he telegraphed HUAC prior to appearing, asking that its subcommittee enter into

${ }^{183}$ Gojack v. United States, 384 U.S. 702 (1966).

${ }_{184}$ Russell v. United States, 369 U.S. 749, 766, 771-72 (1962).

185 See id. at 779 (Clark, J., dissenting).

186 See id. at 781-85 (Harlan, J., dissenting).

187 See Silber v. United States, 370 U.S. 717, 717-18 (1962) (per curiam).

${ }_{188}$ Cf. Russell, 369 U.S. at 751 (majority opinion).

${ }^{189}$ Id. at 773 (Douglas, J., concurring).

${ }^{190} \mathrm{Id}$. at 775-77 (Douglas, J., concurring).

191 Yellin v. United States, 374 U.S. 109 (1963).

192 See id. at 111 \& n.1; see also id. at 135 n.9 (White, J., dissenting) (describing Yellin's other claims in more detail). 
executive session to receive his testimony. ${ }^{193}$ HUAC's Rule IV required an executive session if a majority of the committee or subcommittee believed, among other things, that "a public hearing might ... unjustly injure [the witness's] reputation." "194 But HUAC's Staff Director-rather than HUAC itself-denied Yellin's request. ${ }^{195}$ On this slender reed, Warren built an argument that Rule IV created an individual right to have the committee or subcommittee consider a witness's request for executive session ${ }^{196}$ and that the only means of effectuating this right was to refuse to testify when it was violated. ${ }^{197}$

Warren seems to have had in mind the practice of asking to be held in contempt in order to test the validity of a court order. Yellin had not, however, refused to testify on the grounds of not having had his request for executive session considered, or even mentioned the issue of executive session at all. ${ }^{198}$

Given that Warren could get five votes for his tortured logic in Yellin, one has to wonder why he could not have gotten five votes for the much more straight-forward propositions that HUAC's nebulous mandate made the crime of failing to answer a "pertinent" question unconstitutionally vague and that inquiries into the political beliefs and associations of private citizens can serve no valid legislative purpose (both as suppressing the exercise of free expression and as an intrusion into the realm of the judiciary, viz. punishment). Warren, Douglas, Black, and Brennan had signed on to both propositions in their dissents from Barenblatt. ${ }^{199}$ They had reiterated their concerns in their dissents from Braden ${ }^{200}$ and Wilkinson. ${ }^{201}$ Goldberg was certainly not afraid to strike down aspects of McCarthyism on First Amendment grounds, ${ }^{202}$ and he had told his wife that he intended to be an activist justice. ${ }^{203}$

One possibility for why the Court did not tackle the First Amendment issue in Yellin was that one of the questions Yellin had refused to answer involved his residence prior to $1957 .{ }^{204}$ Since his sentences were to run concurrently, his refusal to answer a single pertinent question would uphold

\footnotetext{
${ }^{193}$ Id. at 111-12 (majority opinion).

194 Id. at 114-15 (quoting HUAC Rule IV).

$195 \mathrm{Id}$. at 112.

196 Id. at $115-18$.

197 Id. at 122.

198 Cf. id. at 135, 139-40 (White, J., dissenting).

199 Barenblatt v. United States, 360 U.S. 109, 139-40, 141-53 (1959) (Black, J., dissenting); id. at 166 (Brennan, J., dissenting).

200 Braden v. United States, 365 U.S. 431, 442-43 (1961) (Black, J., dissenting); id. at 449-50 (Douglas, J., dissenting).

201 Wilkinson v. United States, 365 U.S. 399, 426-28 (1961) (Douglas, J., dissenting).

202 See, e.g., Aptheker v. Secretary of State, 378 U.S. 500, 514 (1964); Gibson v. Florida Legislative Investigation Committee, 372 U.S. 539, 557-58 (1963).

203 Powe, supra note 10, at 211.

204 Yellin, 374 U.S. at 149 (White, J., dissenting).
} 
the conviction, ${ }^{205} \mathrm{a}$ fact that had condemned witnesses in the past. ${ }^{206}$ Attacking the subcommittee's power to ask him any questions at all (because of its failure to follow its own procedures regarding an executive session) would presumably get around this difficulty.

But that explanation cannot suffice regarding the Court's limited holding in Gojack v. United States. ${ }^{207}$ Gojack was one of the six defendants whose convictions had been reversed in Russell, and he had since been reindicted and re-convicted. ${ }^{208}$ The American Civil Liberties Union asked the Court to overrule Barenblatt, noting that the threat of Communism had diminished and could no longer be used to justify curtailing free expression. ${ }^{209}$ In a unanimous opinion by Justice Abe Fortas, the Court nevertheless expressly refused to revisit Barenblatt, instead finding that the HUAC subcommittee's subject of inquiry as stated in Gojack's indictment had not been expressly authorized by HUAC itself, and so Gojack could not be guilty of contempt for refusing to answer questions put to him by that subcommittee. ${ }^{210}$ The Court did not touch the question of whether HUAC could have authorized the subcommittee's line of inquiry, except to note that Rumely prevented HUAC from doing so retroactively. ${ }^{211}$ Black alone wrote separately to say that he would take the opportunity to hold "that the House Un-American Activities Committee's inquiries here amounted to an unconstitutional encroachment on the judicial power for reasons stated in his dissent in Barenblatt v. United States." 212

It is unlikely that Fortas was unwilling as a matter of principle to provide the fifth vote to overrule Barenblatt on the basis of that case's dissenting opinions. While in private practice, when Senator McCarthy had not yet been censured, Fortas had written, "the [congressional] hearing has become a weapon of persecution, a useful tool to the demagogue, a device for the glory of the prosecutor and of shame for the accused." ${ }^{213} \mathrm{He}$ had represented those dragged before the McCarthyite congressional committees. ${ }^{214} \mathrm{He}$ re-iterated the holding in Watkins that "there is no congressional

${ }^{205}$ Id. at $148-49$ (majority opinion).

206 E.g., Barenblatt v. United States, 360 U.S. 109, 115 (1959).

${ }^{207}$ Gojack v. United States, 384 U.S. 702 (1966).

${ }^{208}$ Id . at 704-5. Gojack was a union leader rather than associated with the New York Times, however. See Goodman, supra note 8, at 368.

209 Goodman, supra note 8, at 369.

${ }^{210}$ Gojack, 384 U.S. at 713-15.

211 Id. at 715 \& n. 12 .

${ }^{212} I d$. at 716 (Black, J., concurring). Walter Goodman is therefore incorrect to characterize Gojack as a reprise of Watkins: while both were decided on technical grounds, Gojack lacked the earlier decision's fiery dicta and made no stand for free expression. $C f$. Goodman, supra note 8 at 369.

${ }^{213}$ Quoted in Goodman, supra note 8, at 489.

214 Goodman, supra note 8, at 304; Powe, supra note 10, at 81; Laura Kalman, Abe ForTAS: A BIOGRAPHY 144 (1990) ("He specialized in congressional committees investigating 'un-American' activities.”). 
power to investigate merely for the sake of exposure or punishment, particularly in the First Amendment area," albeit in a footnote. ${ }^{215}$

We must look elsewhere to explain the Court's refusal to drive a stake through HUAC's heart. Unfortunately, the Court's conference notes for Gojack have not been published (nor those for any case discussed in this paper, save Watkins). ${ }^{216}$

Attacking HUAC would not have been beating a dead horse by 1966 . True, it had entered what Walter Goodman was to call its "lean years," 217 but it was still around. The peace movement and the lack of success in Vietnam against which it was directed were being passed off as the work of Communist infiltrators. ${ }^{218}$ HUAC could always turn its gaze upon the civil rights movement, just as it had shifted its focus from fascists to Communists. ${ }^{219} \mathrm{~J}$. Edgar Hoover, HUAC's longtime ally, ${ }^{220}$ was still head of the Federal Bureau of Investigations. ${ }^{221}$ That is, HUAC might have staged a revival.

Thus, while an outright repudiation of the entire McCarthyite congressional investigatory system would not have come too late, Warren may have held off in order to obtain a unanimous opinion to be used in the future, should the need arise. Regardless of the actual value of unanimous opinions, ${ }^{222}$ Warren himself valued them highly. ${ }^{223}$ In Gojack, Warren had an opinion in which Justices Clark, Harlan, Stewart, and White (plus the liberal wing of the Court) agreed that if HUAC was going ruin lives, it had to gets its own hands dirty. No longer could it dispatch a subcommittee to a hotel conference room in Atlanta or Detroit with an open-ended mandate, at least if it wanted the judiciary to condemn recusants. ${ }^{224}$ The Court did not have to reach the question-although it noted its existence-of whether a subcommittee's own wide-ranging statements of its purpose made any prosecutions for contempt of Congress void for vagueness. ${ }^{225}$

If this is the reason why Gojack does not read like the Barenblatt, McPhaul, Wilkinson, and Braden dissents, it means that Gojack represented a real alteration in Warren's strategic thinking about congressional investigative committees, McCarthyite or otherwise. The decision would

${ }^{215}$ Gojack, 384 U.S. at 711 n.9 (majority opinion).

216 Cf. Supreme Court in Conference, supra note 118, at 297-300.

217 See Goodman, supra note 8 at 435.

${ }^{218} I d$. at $482-83$.

${ }^{219} I d$. at $484-86$.

${ }^{220}$ Id. at 416-17; see HoRwITZ, supra note 8, at 65-66.

${ }^{221}$ Cf. John Edgar Hoover, Federal Bureau of Investigations, http://www.fbi.gov/aboutus/history/directors/hoover (Hoover served until his death in 1972).

${ }^{222}$ Cf. Powe, supra note 10, at 44-46; Cass R. Sunstein, Unanimity and Disagreement on the Supreme Court, 100 CoRnell L. Rev. 769 (2015).

${ }^{223}$ Cf. Horwitz, supra note 8, at 23-25 (discussing Brown v. Bd. of Educ. of Topeka, Kansas, 347 U.S. 483 (1953)).

${ }^{224}$ Gojack v. United States, 384 U.S. 702, 708-9 (1966).

${ }^{225}$ Id. at 709 n.7. 
mark a return, not to Watkins and its grand pronouncements, ${ }^{226}$ but to the early days of Quinn, Emspak, and Bart, when the Court demanded that Congress cross every $t$ and dot every $i$. It would be a return to the limits that the Vinson Court was willing to enforce against Congress, ${ }^{227}$ in one case even regarding Communists. ${ }^{228}$ Congress may not investigate in order to right individual wrongs, only to inform itself so that it can exercise its functions intelligently. ${ }^{229}$ Each house can use its own bar to coerce recalcitrant witnesses, ${ }^{230}$ but if it wants to utilize the judiciary's power to punish, it must play by the judiciary's rigid, formalistic rules. ${ }^{231}$ That was the Warren Court's final word on the subject of congressional investigative committees.

226 Contrast Goodman, supra note 8, at 369.

227 See United States v. Rumely, 345 U.S. 41 (1953).

228 Compare Christoffel v. United States, 338 U.S. 84 (1949) with United States v. Bryan, 339 U.S. 323 (1950) and United States v. Fleischman, 339 U.S. 349 (1950).

229 Kilbourn v. Thompson, 103 U.S. 168, 192-93 (1880).

230 Anderson v. Dunn, 19 U.S. 204, 230-31 (1821). Some cases had even suggested that Congress could not punish at all, only use coercion to obtain compliance. E.g., Marshall v. Gordon, 243 U.S. 521, 542-45 (1917); Anderson, 19 U.S. at 230-31; see also Wilkinson v. United States, 365 U.S. 399, 430 (1961) (Brennan, J., dissenting) (because there was no reasonable prospect that Wilkinson would answer the subcommittee's questions, its purpose in imprisoning him could not have been to facilitate factgathering). When one witness burned the records rather than comply with a subpoena, however, the Court said those earlier decisions were dicta and permitted retributive punishment. Jurney v. MacCracken, 294 U.S. 125, 148-49 (1935). That case, however, noted the possibility of judicial review as enervating the policy reason for denying Congress the power to punish. Jurney, 294 U.S. at 150.

231 See Gojack v. United States, 384 U.S. 702,714 (1966); Russell v. United States, 369 U.S. 749, 759-60 (1962); Deutch v. United States, 367 U.S. 456, 471 (1961); Sacher v. United States, 356 U.S. 756, 757 (1958); Watkins v. United States, 354 U.S. 178, 207-8 (1957); see also McPhaul v. Unites States, 364 U.S. 372, 387 (1960) (Douglas, J., dissenting); United States v. Fleischman, 339 U.S. 349, 380 (Frankfurter, J., dissenting); cf. Christoffel, 338 U.S. at 89. 